\title{
METALS IN BIOLOGY GORDON RESEARCH CONFERENCE
}

\author{
18-22 January 1998, \\ Harbortown Hotel, Ventura, California
}

Conference Chair

Kenneth D. Karlin

Department of Chemistry

Johns Hopkins University

Baltimore, MD 21218-2685, USA

\author{
Conference Co-Chair \\ Eckard Münck \\ Department of Chemistry \\ Carnegie-Mellon University \\ Pittsburgh, PA 15213, USA
}

\section{PROGRAM:}

BIOINORGANIC CHEMISTRY AND BIOGEOCHEMICAL CYCLES

Ed Stiefel (Exxon Company), Bioinorganic chemistry and biogeochemical cycles

IRON SULFUR CLUSTERS

Dimitri Coucouvanis (U. Michigan), Partial structural analogs for the nitrogenase cofactor

Barbara Burgess (UC Irvine), The mechanism of Ferredoxin I mediated regulation of $\mathrm{NADPH}$ :ferredoxin reductase in Azotobacter vinelandii

Lance Seefeldt (Utah State U.), Electron transfer reactions and MgATP hydrolysis in nitrogenase catalysis

Joan Broderick (Amherst College), Pyruvate formate lyase activase: Radical generation by an Fe-S cluster

ZINC PROTEASES

Carl Decicco (Dupont Merck), Zinc metalloproteinases and drug discovery

Rick Holz (Utah State U.), Mechanistic studies on peptide hydrolysis by dinuclear metalloenzymes

METAL REGULATION AND PROCESSING

Richard Palmiter (HHMI; U. Washington), Vesicular zinc

Tom O'Halloran (Northwestern), Getting metal ions to the right place in the cell: chaperone proteins and vesicles

Bob Hausinger (Michigan State U.), Nickel incorporation into urease

Jerry Kaplan (U. Utah), Yeast mitochondrial iron metabolism: Insights into human disease

MEDICINE AND DIAGNOSTICS

Steve Lippard (MIT), On the biological mechanism of cisplatin

Tom Meade (Cal Tech), New MRI contrast agents: Progress towards monitoring gene expression in vivo.

PEROXYNITRITE AND NITROGEN OXIDE BIOLOGY/CHEMISTRY

Mike Stern (Monsanto Company), Peroxynitrite decomposition catalysts. Novel therapeutics for peroxynitrite-mediated pathology

John Groves (Princeton U.), Biological targets of peroxynitrite. Redox pathways, mechanisms and membrane permeability

Peter Kroneck (U. Konstanz, Germany), Nitrous oxide reductase, a copper enzyme with novel chromophores

Mike Marletta (HHMl; U. Michigan), Piecing together cofactors and mechanism in nitric oxide synthase

PHYSICAL STUDIES ON ELECTRON TRANSFER CENTERS

Eckard Münck (Carnegie-Mellon U.), On the nature of the A- and C-clusters of $\mathrm{CO}$ dehydrogenase Claudio Luchinat (U. Florence, Italy), Ferredoxins and cytochromes: beyond the solution structure

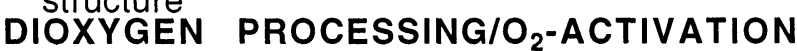

Dan Stack (Stanford University), Catalytic functional model of galactose oxidase

Ninian Blackburn (Oregon Grad Inst.), Peptidylglycine alpha-hydroxylating monooxygenase:

structure and, mechanism.

Chris Schofield (Oxford U., UK), Structures and mechanisms of non-heme iron

oxygenases

Anne-Francis Miller (Johns Hopkins U.), The basis for metal ion specificity in Fe- and Mnsuperoxide dismutase John Caradonna (Yale U.), Interactions of reduced dioxygen species with non-heme iron centers: from synthetic models to proteins

BIOINORGANIC DISEASE STATES (Joint Session with Graduate Research Seminar (GRS)) Joan Valentine (UCLA), Searching for the link between $\mathrm{Cu}-\mathrm{Zn}$ superoxide dismutase and ALS

Questions and/or request for Applications: GRC Web site: http://www.grc.uri.edu

GRC E-mail: grc@grcmail.grc.uri.edu

Professor Kenneth D. Karlin

Phone: + 1 410-516-8027; Fax: + 1 410-516-6164 (direct]; Fax: + 1 410-516-8420 (Chem. Dept.] Email: karlin@jhuvms.hcf.jhu.edu 